\title{
PEMBELAJARAN MENULIS TEKS CERITA DONGENG BERBASIS KEARIFAN LOKAL PADA SISWA KELAS IV
}

\author{
Heny Kusuma Widyaningrum \\ PGSD Universitas PGRI Madiun \\ heny@unipma.com
}

\begin{abstract}
The objectives this research are to (1) plan teaching learning of writing the fairy tale text based on local wisdom to fourth-grade students of SDN Kedungputri 02, Ngawi (2) do teaching learning of writing the fairy tale text based on local wisdom to the fourth-grade students of SDN Kedungputri 02, Ngawi (3) evaluate teaching learning of writing the fairy tale text based on local wisdom to the fourth grade students of SDN Kedungputri 02, Ngawi. The subject of this research was the fourth-grade students and classroom teacher of the fourth-grade in SDN Kedungputri 02, Ngawi. The object of this research was teaching learning of writing the fairy tale text based on local wisdom. This study was using descriptive qualitative study. The aim was to obtain a clear, objective, and systematic image about the facts. The results showed that teacher have three stages, they are the plan of the learning, the teaching learning, and evaluation of the learning. In the plan of teaching learning, the teacher made complete lesson plan (RPP) based on components of RPP on the 2013-curciculum. In teaching learning, teacher and students do activities. There are three teacher activities in learning: the introduction, the core, and the cover. Teachers assess students in attitude assessment through observation techniques, knowledge assessment through oral and written tests, while fairy tale skills assessment through practice tests.
\end{abstract}

Keywords: Writing, fairy tale text, local wisdom.

\begin{abstract}
Abstrak : Penelitian ini bertujuan mendeskripsikan (1) perencanaan pembelajaran menulis teks cerita dongeng berbasis kearifan lokal pada siswa kelas IV di SDN Kedungputri 02, Ngawi (2) pelaksanaan pembelajaran menulis teks cerita dongeng berbasis kearifan lokal siswa kelas IV di SDN Kedungputri 02, Ngawi , (3) evaluasi pembelajaran menulis teks cerita dongeng berbasis kearifan lokal pada siswakelas IV di SDN Kedungputri 02, Ngawi. Siswa kelas IV dan guru kelas kelas IV SDN Kedungputri 02, Ngawi merupkan subjek penelitian. Objek penelitian ini adalah pembelajaran menulis teks cerita dongeng berbasis kearifan lokal. Penelitian ini merupakan penelitian deskriptif yang bertujuan mendapatkan pendeskripsian yang jelas, objektif, dan sistematis tentag fakta-fakta yang ada selama penelitian. Hasil penelitian ini yaitu guru melaksanakan tiga tahapan, yang dimulai dengan perencanaan, pelaksanaan, dan evaluasi pembelajaran. Pada tahap perencanaan, guru membuat RPP K-13 lengkap berdasarkan komponen-komponennya. Pada tahap pelaksanaan, guru dan siswa melakukan suatu aktivitas. yang dilakukan oleh guru dan siswa. Ada tiga aktivitas guru dalam pembelajaran: pendahuluan, inti, dan adanya penutup. Guru menilai siswa dalam penilaian sikap melalui teknik pengamatan, penilaian pengetahuan melalui tes lisan dan tulis, sedangkan penilaian keterampilan dongeng melalui tes praktik.
\end{abstract}

Kata kunci: Keterampilan menulis, teks cerita dongeng, kearifan lokal. 


\section{PENDAHULUAN}

Penerapakan Kurikulum 2013

di sekolah saat ini merupakan serangkaian kurikulum yang disempurnakan yang dirintis sejak tahun 2004 dengan kurikulum 2006 (KTSP) (Kurinasih dan Berlin, 2014:32). Kurikulum 2013 yang sedang berlangsung saat ini mengutamakan keterampilan, pemahaman, dan pendidikan berkarakter. Siswa juga dituntut aktif dalam berdiskusi memiliki sopan santun, dan nilai religius yang tinggi.

Kurikulum 2013 tidak hanya menuntut guru dalam perubahan konsep, metode, komitmen, dan strategi pendekatan, tetapi juga mencanangkan pembelajaran berbasis teks. Oleh karena itu, siswa dituntut mampu memproduksi sebuah teks.

Pembelajaran bahasa Indonesia juga memiliki tujuan, salah satunya yaitu berkomunikasi dengan efektif, efisien, dan sesuai etika yang berlaku, baik secara lisan dan tulis(Abidin, 2012: 14). Oleh karena itu, Pembelajaran bahasa Indonesia mempunyai empat keterampilan yang wajib dikuasai oleh siswa. Keempat keterampilan tersebut, yaitu menyimak atau mendengarakan, membaca, berbicara, dan menulis.

Pembelajaran keterampilan menulis termasuk dalam keterampilan yang penting dalam berkomunikasi dengan baik dan benar, khususnya dalam berkomunikasi tulisan. Menurut Akhadiah (1996: 158) menjelaskan bahwa menulis merupakan penyajian dari gagasan, pendapat, dan perasaan ke dalam bentuk tulisan.

Dalam pembelajaran bahasa Indonesia, keterampilan menulis termasuk keterampilan yang kompleks dan rumit untuk dikuasai karena banyak aturan-aturan yang harus dilakukan. Dengan demikian, aturan-aturan dalam keterampilan menulis harus diperhatikan agar pesan yang disampaikan penulis bisa diterima dengan baik.

Aturan-aturan keterampilan menulis masing-masing teks berbedabeda. Pada siswa kelas IV, siswa sudah dituntut untuk menulis teks cerita dongeng. Menurut Suharma (2006: 57), menjelaskan bahwa latihan menulis kembali suatu dongeng dari hasil bacaan atau dari hasil simakan, langkah-langkah yang dilakukan adalah (1) mendengarkan atau membaca kembali dongeng yang akan ditulis, (2) memperhatikan bagian demi bagian dongeng dari awal hingga akhir, (3) mengingat kembali alur cerita, pemain atau tokoh, dan unsur-unsur yang lain, (4) membayangkan atau berimajinasi adegan dongeng, seolah-olah pembaca terlibat dalam isi dongeng tersebut, dan (5) menulis kembali suatu isi dari dongeng dengan menggunakan bahasa Indonesia yang baik dan benar.

Sebagian besar guru dan siswa beranggapan bahwa kegiatan menulis merupakan keterampilan yang paling sulit karena banyak unsur yang terlibat, seperti unsur kebahasaan, isi, dan ragam tulisan. Jadi, keterampilan menulis tidak hanya dituntut untuk dapat menyusun isi tulisan, tetapi juga harus mampu menuangkan gagasannya dalam bentuk tulisan yang dipahami oleh pembaca.

Kurikulum 2013 dalam pembelajaran bahasa Indonesia merupakan pembelajaran berbasis teks. Oleh karena itu, melalui kegiatan menulis, siswa dapat dilatih dalam 
berbagai materi yang berkaitan dengan teks di sekolah dasar. Beberapa materi bahasa Indonesia yang sesuai dengan pembelajaran menulis dalam Kurikulum 2013, antara lain menulis puisi, teks fiksi, teks deskripsi, teks percakapan, dan teks laporan, dan teks eksplanasi.

Salah satu jenis teks fiksi dalam materi bahasa Indonesia adalah cerita dongeng. Menurut Sugeng (2005: 126) isi dari dongeng adalah suatu ungkapan mengenai hal-hal yang bersifat permukaan dan sendi kehidupan masyarakat secara mendalam. Dapat dijelaskan pula bahwa cerita dongeng yang dikarang isinya berupa pandangan hidup masyarakat pemilik daerah masing-masing yang dijelaskan secara detail. Kehadiran dongeng menjawab teka-teki dari alam yang ada dalam kehidupan suatu masyarakat pendukungnya.

Materi cerita dongeng dalam pembelajaran bahasa Indoensia di sekolah dasar dapat menjadi sarana yang baik siswa dalam tumbuh kembangnya empati anak. Selain itu, dongeng juga bermanfaat sebagai sarana hiburan dan pendidikan moral.

Cerita dongeng dalam pembelajaran sastra mempunyai nilainilai kearifan lokal, salah satunya munculnya nilai moral. Nilai moral berfungsi untuk membuat siswa menjadi seseorang yang lebih baik dalam lingkungan bermasyarakat. Hal tersebut ditegaskan pendapat Sumayana (2017: 21) bahwa kearifan lokal dalah pandangan hidup, ilmu pengetahuan, dan strategi kehidupan berupa aktivitas yang dilakukan oleh masyarakat lokal untuk menjawab masalah dalam pemenuhan kebutuhan mereka. Rahyono (dalam Fajarini : 2104: 124) menambahkan bahwa kearifan lokal pada setiap cerita di setiap daerah setempat merupakan kecerdasan yang dimiliki oleh kelompok masyarakat etnis tertentu yang didapatkan melalui pengalaman masyarakat itu sendiri.

Kearifan lokal milik masyarakat tertentu, dianggap dapat mempertahakan arus globalisasi karena kearifan lokal tersebut mempunyai nilai-nilai yang berfungsi sebagai sarana atau tempat pembangunan karakter bangsa (Yunus, 2014: 37). Dengan adanya sarana pembentukan karakter bangsa, siswa yang mempelajari cerita dongeng berbasis kearifan lokal juga akan terbentuk pendidikan karakter dalam diri mereka.

Tidak hanya pembentukan karakter bangsa, apabila pembelajaran berbasis kearifan lokal digunakan dalam acuan pengembangan pendidikan, pendidikan tidak hanya menghasilkan kemajuan di bidang penguasaan ilmu pengetahuan dan teknologi saja, tetapi juga sebagai wadah pelestarian budaya dan identitas bangsa (Subagia \& Wiratama dalam Suastra, 2005: 88). Oleh karena itu, dengan adanya penelitian pembelajaran sastra yang memuat materi cerita dongeng berbasis kearifan lokal, siswa mendapatkan manfaat berupa pengetahuan dan pelestarian budaya secara bersamaan.

Pengintegrasian budaya dalam pembelajaran di sekolah dasar dapat berupa kearifan lokal. Pengintegrasian kearifan lokal pada matapelajaran bahasa Indonesia di kelas IV salah satunya keterampilan menulis teks cerita dongeng.

Penelitian yang berjudul "Pembelajaran menulis teks cerita dongeng berbasis kearifan lokal pada siswa kelas IV" perlu dilakukan karena dapat memperluas wawasan penelitian yang telah ada. Selain itu, penelitian ini 
juga efektif dalam meningkatkan mutu keterampilan menulis siswa pada pembelajaran bahasa Indonesia di kelas IV. Tujuan penelitian ini adalah mendeskripsikan (1) perencanaan pembelajaran menulis teks cerita dongeng berbasis kearifan lokal siswa kelas IV di SDN Kedungputri 02, Ngawi (2) pelaksanaan pembelajaran menulis teks cerita dongeng berbasis kearifan lokal siswa kelas IV di SDN Kedungputri 02, Ngawi, (3) evaluasi pembelajaran menulis teks cerita dongeng berbasis kearifan lokal siswa kelas IV di SDN Kedungputri 02, Ngawi.

\section{METODE PENELTIAN}

Penelitian ini menggunakan rancangan penelitian deskriptif karena menggambarkan secara utuh pembelajaran menulis teks cerita dongeng berbasis kearifan lokal. Hal tersebut sejalan dengan tujuan pelaksanaan penelitian deskriptif, yaitu memberikan gambaran suatu kasus secara tepat (Jabrohim , 2001:32).

Sumber data penelitan ini ialah pembelajaran keterampilan menulis teks cerita dongeng berbasis kearifan lokal siswa kelas IV. Pembelajaran pada penelitian ini difokuskan pada tiga hal. Pertama, perencanaan pembelajaran menulis teks cerita dongeng dalam hal ini RPP (Rencana Pelaksanaan Pembelajaran). Kedua, pelaksanaan pembelajaran keterampilan menulis teks cerita dongeng dilakukan oleh pihak guru dan siswa kelas IV. Ketiga, penilaian pembelajaran.

Metode pengumpulan data yang dilakukan dalam penelitian ini adalah observasi kelas, wawancara oleh guru dan siswa, dan dokumentasi. Penelitian ini dilaksanakan pada semester ganjil, tepatnya tanggal 16 Oktober 2017. Data yang terkumpul lalu dianalisis dengan model analisis interaktif (Miles \& Huberman, 1984: 23). Empat komponen analisis model milik Miles dan Huberman tersebut adalah pengumpulan data, reduksi, display, dan penarikan kesimpulan.

\section{HASIL DAN PEMBAHASAN Hasil}

Hasil penelitian pembelajaran menyusun teks cerita dongeng berbasis kearifan lokal terdiri dari tiga tahapan: perencanaan yang dilakukan guru, pelaksanaan yang dilakukan guru dan siswa, dan penilaian hasil kerja siswa. Saat tahap perencanaan, perencanaan pembelajaran menyusun teks cerita dongeng berbasis kearifan lokal yang dirancang oleh guru masih belum memenuhi komponen. Komponen dalam pembuatan RPP Kurikulum 2013 (K-13) yang sudah terpenuhi, yaitu identitas, perumusan indikator dan tujuan yang dicapai, pemilihan dan penjelasan materi, sumber dan media belajar, kegiatan pembelajaran, dan penilaian siswa.

Saat menganalisis RPP K-13 yang dimiliki guru, kekurangan guru, yaitu apada identitas nama, guru tudak mencantumkan sub sub tema. Hanya tema saja yang dicantumkan. Selain itu, pencantuman alokasi waktu belum secara bertahap serta pemaparan materi belum lengkap. Materi pada bahasa Indonesia kurang dalam pemaparan hakikat cerita dongeng dan cara penulisan kembali cerita dongeng. Namun, pada dasarnya semua komponen RPP K-13 sebagian besar telah memiliki kesesuaian dengan aspek yang terdapat dalam setiap komponen yang ada.

Pada tahap pelaksanaan, pelaksanaan pembelajaran menyusun 
teks cerita dongeng berbasis kearifan lokal dilaksanakan tiga kegiatan: pendahuluan, inti, dan penutup. Ketiga kegiatan pembelajaran tersebut dijabarkan secara detail pada penjabaran berikut ini.

Pada kegiatan pendahuluan, guru mengawali pembelajaran melalui apersepsi dan motivasi. Kegiatan apersepsi dilakukan dengan menghubungkan pengalaman nyata siswa dengan pembelajaran sebelumnya. Selain itu, guru juga tidak lupa menjelaskan kompetensi yang dicapai dan rencana kegiatan yang akan diajarkan.

Pada kegiatan inti, guru melaksanakan kegiatan pembelajaran dan menunjukkan penguasaannya terhadap materi menyusun teks cerita dongeng. Guru juga merancang menerapkan strategi dan metode pembelajaran yang bersifat mendidik. Pendekatan saintifik juga diterapkan karena sebagai pendekatan yang wajib dalam pembelajaran Kurikulum 2013, khususnya pembelajaran menulis teks cerita dongeng. Ciri khas dari pendekatan saintifik adalah adanya kegiatan 5M, yaitu Mengamati, Menanya, Menganalisis, Menalar,

dan Mengomunikasikan. Untuk mendukung pembelajaran, guru menggunakan sumber belajar dan media dalam pembelajaran. Sumber belajar siswa yaitu berupa teks cerita dongeng berbasis kearifan lokal yang berjudul "Asal Muasal Telaga Pasir". Cerita tersebut merupakan cerita dongeng lokal asal Magetan. Selain itu, media belajar yang digunakan guru berupa gambar yang mendukung cerita dongeng.

Dalam pembelajaran di kelas, guru juga melibatkan siswa dalam aktivitas belajar. Guru mendorong siswa agar aktif dalam bertanya. Penggunaan bahasa yang benar dan tepat, seperti penggunaan kalimat lugas dan pemberian contoh nyata kepada siswa, juga digunakan oleh guru sehingga siswa dapat memahami materi pelajaran cerita dongeng dengan baik. Setelah pemberian penjelasan oleh guru, siswa menyimak cerita dongeng berjudul “Asal Muasal Telaga Pasir"dengan cermat.

Penilaian yang dilakukan guru dalam menuliskan kembali teks cerita dongeng berbasis kearifan lokal berupa penilaian sikap dengan melakukan pengamatan secara langsung terhadap siswa. Penilaian pengetahuan dilakukan oleh guru secara lisan dan tulisan. Penilaian tersebut dilakukan disela-sela saat guru menjelaskan materi cerita dongeng. Penilaian keterampilan dilakukan oleh guru saat siswa mendapatkan tugas menuliskan kembali teks cerita dongeng dengan melakukan diskusi kelompok.

\section{Pembahasan}

Dalam penelitian ini, terdapat tiga temuan yang dapat dikaitkan dengan pembelajaran menulis teks cerita dongeng berbasis kearifan lokal. Ketiga temuan tersebut berupa perencanaan , pelaksanaan, dan penilaian pembelajaran.

Guru sudah merancng RPP K13 berdasarkan komponen-komponen kurikulum K-13. Namun, dalam pengembangan komponen RPP-nya belum maksimal. Ada beberapa komponen yang harus diperbaiki, yaitu tema belum dispefikasikan ke dalam sub tema, belum ada pembagian alokasi waktu menjadi beberapa tahap, dan kurang lengkap memaparkan teori mengenai cerita dongeng dan cara penulisan teks cerita dongeng di dalam RPP. 
RPP yang seharusnya bertujuan untuk memperlancar dan mempermudah pembelajaran di kelas, masih terlihat belum maksimal karena terkesan hanya sebagai kepentingan administrasi sekolah (formalitas). Oleh karena itu, hendaknya guru melengkapi beberapa komponen yang belum tercapai dengan lengkap sehingga ke depannya akan memudahkan guru dalam melakukan praktik pembelajaran.

Pelaksanaan pembelajaran adalah pengaplikasian dari perencanaan pembelajaran yang dibuat oleh guru, yaitu RPP. Jadi, pelaksanaannya bergantung pada perencanaan pengajaran. Namun, kenyataannya pada RPP yang telah dibuat guru, cukup susah untuk menyamakan dengan praktik di kelas.

Kegiatan pembelajaran adalah proses keaktivan siswa dalam mengembangkan potensinya. Dengan demikian, siswa akan memiliki ilmu pengetahuan dan terampil dalam kegiatan menulis teks. Hal tersebut didukung oleh Muslich (2008:75) bahwa dalam pembelajaran di kelas guru menggunakan metode ceramah saja, siswa hanya mengingat $20 \%$ dari sesuatu yang didengarnya. Sebalikanya, jika guru melaksanakan pembelajaran dengan siswa diberikan tugas-tugas dan mempresetasikan hasilnya, siswa dapat mengingat sampai $90 \%$ dari sesuatu yang dikerjakan dalam bentuk laporan lisan atau tulis.

Kondisi yang dihadapi guru dalam melaksanakan pembelajaran menuliskan kembali teks cerita dongeng mendapatkani pengaruh yang cukup besar terhadap kelancaran proses pembelajaran. Guru seharusnya sadar terhadap situasi dalam proses pembelajaran. Artinya, guru mampu mengondisikan siswa dan menciptakan suasana belajar yang dapat membuat siswa berhasil mencapai tujuan pembelajaran yang sudah direncanakan dalam RPP K13. Hal tersebut senada dengan pendapat Bower dan Hilgard (2008:45) menjelaskan bahwa belajar mempunyai hubungan dengan perilaku dan situasi atau suasana tertentu yang disebabkan pengalaman yang berulang kali dalam situasi tersebut. Perubahan tingkah laku itu tida bisa diterangkan kerena kecenderungan respon pembawaan, kematangan manusia, atau suatu keadaan sesaat manusia .

Evaluasi merupakan salah satu aspek yang wajib dimiliki oleh guru agar dapat mengetahui suatu tingkat pemahaman dalam diri siswa terhadap materi yang dipelajari sebelumnya. Tujuan dari evaluasi adalah mengetahui kemampuan siswa, baik dari aspek afektif, kognitif, dan psikomotor selama proses proses pembelajaran.

Evaluasi yang dilakukan guru berupa penilaian tes lisan dan tulis. Tes lisan dilakukan setelah guru menerangkan hakikat cerita dongeng dan cara penulisan kembali cerita dongeng yang benar. Guru memberikan peluang atau kesempatan bertanya kepada jika ada materi yang kurang dimengerti atau kurang dipahami siswa.

Guru memantau perkembangan belajar siswa dengan melihat apakah siswa mampu memahami dan menjawab pertanyaan yang diajukan oleh guru. Nilai tersebut disesuaikan dengan tugas siswa dalam menyusun kembali teks cerita dongeng yang berjudul Asal Muasal Telaga Pasir. Penilaian dilakukan dengan menyesuaikan pedoman penskoran pada tiap-tiap instrument dalam RPP. Hasil pekerjaan siswa terkait dengan pembelajaran menulis teks cerita dongeng berbasis kearifan lokal sudah mencapai nilai 
ketuntasan dengan nilai rata-rata sebesar 80,35 .

Tujuan utama dalam evaluasi proses pembelajaran adalah unutk memperoleh pemahaman mengenai strategi pembelajaran, cara atau metode pembelajaran, dan media pembelajaran. Evaluasi pembelajaran sebagian besar sesuai tujuan yang ingin dicapai oleh guru. Hal tersebut sesuai dengan tujuan pembelajaran terkait evaluasi. Alat evaluasi yang digunakan sudah jelas yaitu berupa instrument yang berbunyi susunlah kembali sebuah teks cerita dongeng yang berjudul Asal Muasal Telaga Pasir yang diperdengarkan oleh guru dengan pemilihan kata yang tepat dan sesuai dengan PUEBI.

\section{SIMPULAN DAN SARAN}

Simpulan

Perencanaan pembelajaran menulis teks cerita dongeng berbasis kearifan lokal yang dilakukan oleh guru kelas IV telah disusun berupa silabus dan RPP. Dalam penyusunan silabus, guru telah mengkaji $\mathrm{KI}$ dan $\mathrm{KD}$, mengembangkan indikator dan tujuan pembelajaran, membuat materi pembelajaran, mengembangkan kegiatan pembelajaran, penilaian, dan menentukan sumber belajar. Setelah itu, guru telah menyusun RPP dengan menjabarkan setiap kegiatan lebih rinci dari silabus yang sudah disusun sebelumnya.

$$
\text { Pada saat melaksanakan }
$$

evaluasi pembelajaran menulis teks cerita dongeng, laporan hasil penilaian keterampilan siswa sebaiknya memperhatikan kisi-kisi dalam penyusunan teks cerita dongeng. Penyusun teks cerita dongeng juga dinilai berdasarkan pemilihan kata yang tepat serta penggunaan PUEBI.
Pelaksanaan pembelajaran Menulis teks cerita dongeng berbasis kearifan lokal yang dilakukan oleh guru kelas IV telah dilaksanakan secara sistematis, dimulai pendahuluan, inti, dan penutup. Pada pelaksanaan pembelajaran, selain guru membacakan cerita dongeng lokal berjudul Asal Muasal Telaga Pasir, guru juga menampilkan gambar yang mendukung cerita untuk membantu siswa menemukan ide dalam menulis teks cerita dongeng.

Pelaksanaan evaluasi pembelajaran menulis teks cerita dongeng berbasis kearifan lokal yang dilakukan oleh guru kelas IV telah dilakukan berdasarkan pemilihan kata atau diksi dan penggunaan PUEBI yang tepat. Evaluasi dilakukan secara individu, tetapi dapat dikerjakan secara berdiskusi. Guru kelas IV memiliki format penilaian khusus sehingga penilaiannya berlangsung efektif dan efisien.

\section{Saran}

Dalam penyusunan RPP menulis teks cerita dongeng berbasis kearifan lokal, guru sebaiknya memilih metode pembelajaran dan media belajar sesuai dengan kemampuan dan karakter siswa. Tujuannya agar pembelajaran menulis cerita dongeng yang diajarkan dapat dipahami siswa dengan baik.

\section{DAFTAR RUJUKAN}

Abidin, Yunus. (2012). Pembelajaran Bahasa Indonesia Berbasis Pendidikan Karakter. Bandung: PT Refika Aditama.

Akhadiah, dkk. (1996). Menulis. Bandung: Dikbud.

Bower, G. H. \& Hilgard, E. R. (1981). Theories of Learning. 
Englewood Cliffs New Jersey: Prentice Hall.

Fajarini, Ulfah. (2014). Peranan Kearifan Lokal dalam Pendidikan Karakter. Sosio Didaktika. Vol 1 no 2.

Jabrohim. (2001). Metodologi Penelitian Sastra. Yogyakarta: Hinindita Graham Widya.

Kurinasih, Imas dan Berlin Sari. (2014). Impelmentasi Kurikulum 2013 Konsep dan Penerapan. Surabaya. Kata Pena.

Muslich, Mansur. (2008). KTSP. Pembelajaran Berbasis Kompetensi dan Kontekstual. Panduan Bagi Guru. Kepala Sekolah dan Pengawas Sekolah. Jakarta : Bumi Aksara.

Rahyono. F.X. (2009). Kearifan budaya dalam kata. Jakarta: Wedatama Widyasastra.
Suastra, I.W. (2005). "Mengembangkan Pendidikan Berbasis Budaya Lokal di Sekolah. Jurnal Pendidikan dan Pengajaran" Jurnal Pendidikan, Volume 38, (3).

Sugeng. (2005). Bahasa dan Sastra Indonesia Kelas VII SMP dan MTs. Jakarta : Bumi Aksara.

Suharma, (2006). Bahasa dan Sastra Indonesia SMP Kelas VII. Bogor : Yudhistira

Sumayana, Yena. (2017). Pembelajaran Sastra di Sekolah Dasar Berbasis Kearifan Lokal (Cerita Rakyat). Mimbar Sekolah Dasar. Vol 4 (1) 2017.

Yunus, Risaid. (2014). Nilai-nilai Kearifan Lokal (Local Genius) sebagai Penguat Karakter Bangsa: Studi Empiris Tentang Huyula. Yogyakarta: Deepublish. 